\title{
The Commission, the Politics of Information and the European Public Sphere
}

Citation for published version (APA):

Bijsmans, P. H. M. G. (2014). The Commission, the Politics of Information and the European Public Sphere. In T. Blom, \& S. Vanhoonacker (Eds.), The Politics of Information. The Case of the European Union (pp. 179-192). Palgrave Macmillan. European Administrative Governance https://doi.org/10.1057/9781137325419_12

Document status and date:

Published: 01/01/2014

DOI:

10.1057/9781137325419 12

Document Version:

Publisher's PDF, also known as Version of record

Document license:

Taverne

Please check the document version of this publication:

- A submitted manuscript is the version of the article upon submission and before peer-review. There can be important differences between the submitted version and the official published version of record.

People interested in the research are advised to contact the author for the final version of the publication, or visit the DOI to the publisher's website.

- The final author version and the galley proof are versions of the publication after peer review.

- The final published version features the final layout of the paper including the volume, issue and page numbers.

Link to publication

\footnotetext{
General rights rights.

- You may freely distribute the URL identifying the publication in the public portal. please follow below link for the End User Agreement:

www.umlib.nl/taverne-license

Take down policy

If you believe that this document breaches copyright please contact us at:

repository@maastrichtuniversity.nl

providing details and we will investigate your claim.
}

Copyright and moral rights for the publications made accessible in the public portal are retained by the authors and/or other copyright owners and it is a condition of accessing publications that users recognise and abide by the legal requirements associated with these

- Users may download and print one copy of any publication from the public portal for the purpose of private study or research.

- You may not further distribute the material or use it for any profit-making activity or commercial gain

If the publication is distributed under the terms of Article $25 \mathrm{fa}$ of the Dutch Copyright Act, indicated by the "Taverne" license above, 


\section{2 \\ The Commission, the Politics of Information, and the European Public Sphere}

Patrick Bijsmans

The seemingly inadequate development of a European public sphere to discuss and form opinions on important matters of public affairs has become an important topic in debates about the European Union's democratic deficit (European Commission 2006b; Follesdal and Hix 2005). ${ }^{1}$ Research focuses on how EU affairs are discussed in or covered by national media (Koopmans and Statham 2010), but also increasingly pays attention to the information and communication policies of the institutions (Martins et al. 2012). This chapter introduces the latter perspective into this volume. Brüggemann $(2010,7)$ writes that 'filnformation policy is a set of political decisions', a statement that can also be extended to communication policy. As such, this chapter will predominantly focus on 'constitutive politics', that is, on 'the choices that have to be made in the institutionalization of the provision of information and...the contestability of these choices and the interests involved' (Blom, Chapter 2 in this volume).

Since the early 1990s, information and communication have been the focus of several EU initiatives (European Commission 2002b). This was partly the result of the narrow approval of the Maastricht Treaty in 1993 that resulted in a call for more transparency. Yet at this time the number of Brussels journalists that were more critical of the EU was also increasing. In addition, it was widely believed that the inadequate reaction to the crisis resulting from fraud allegations against Commissioner Cresson partly explained why the Santer Commission eventually had to step down in 1999 (Meyer 1999).

The rejection of the Constitutional Treaty in 2005 presented yet another challenge. In the aftermath, the Barroso I Commission 
(2004-2009) was explicitly tasked by the European Council to come up with new information and communication proposals. ${ }^{2}$ In a series of documents, the Commission did not just present plans for internal reforms, but also argued for stronger inter-institutional cooperation. Communication was to become a policy in its own right and, for the first time, a Commissioner for Communication Strategy was appointed in the person of Margot Wallström.

This chapter discusses the attempts of the Barroso I Commission to formulate a more efficient EU information and communication policy, and, in particular, how internal Commission dynamics and relations among the institutions inhibited many of the proposed reforms. The chapter starts by introducing some of the basic ideas linked to democracy, communication, and the (European) public sphere. The next part presents the main proposals put forward by the Barroso I Commission first, regarding internal reforms, and, second, concerning the envisaged concerted institutional effort. Subsequently, the chapter outlines some of the main challenges involved. This will be illustrated by references to official documents, interviews with practitioners-and other research.

\section{Setting the scene: democracy, communication, and} the public sphere

Modern democracy is mainly characterized by representative features, with professional politicians acting as representatives of citizens, and the exchange of information and opinions - the communication between citizens and their representatives - predominantly taking shape through mass media. As Karen Sanders $(2009,24)$ writes, democratic politics is 'irredeemably public, constituting by words and deeds a sphere where human beings and groups must make known to fellow citizens their views, their opinions, their policies'.

Political actors have various means at their disposal to generate publicity and support in the public sphere. They try to 'spin' the news, by setting the agenda themselves, but also by attempting to become associated with other newsworthy events as a way of boosting their own visibility, or by bypassing critical journalists, selectively using information, or even preventing information from becoming public and sparking unwanted debates (Eilders et al. 2004, 222). Media and communication experts assist by gathering data, devising media strategies, and guarding a coordinated communication effort.

Media play a key role in the interaction between citizens and political actors, as channels for communication, sources of information, and arenas for public debate. They play an active part in this respect, for example, by selecting certain stories or by presenting issues in particular ways. This leads to a tension between, on the one hand, a political logic that emphasizes the importance of communication as a way of gathering citizen support, and, on the other hand, a media logic that emphasizes attractive stories, not necessarily the intricate process of policy-making. Obviously, this limits the possibilities of political actors to get their message across. ${ }^{3}$

Much of the interaction between political actors and journalists engaged in EU affairs takes place around Rond-point Schuman in Brussels, a stone's throw away from the main institutions, the Commission, the EP, and the Council. Like national actors, these institutions draft communication strategies, issue press releases, organize photo opportunities, offer audio-visual facilities for journalists, and so forth (Kopper et al. $2007,81)$. However, until the Maastricht ratification crisis (1992/1993), information and communication were not very high on the EU agenda (Meyer 1999, 624). After Maastricht, many European politicians believed that a lack of information explained the public's growing scepticism and transparency became an important focus of EU policy, mostly covering public access to documents. Yet, while perhaps desirable, more transparency does not automatically result in increased citizen awareness of and involvement in Union affairs. It needs to be accompanied by communication to make citizens conscious of the availability of information (Hüller 2007).

The ongoing debates about the EU's democratic deficit and increased scepticism among European citizens have only further increased the importance of information and communication. Yet, conflicting political and media logics are also important in the EU context. Brussels correspondents appreciate the relative openness compared to that of many national governments, but also criticize, for instance, the use of jargon, the tendency to 'celebrate' integration and the absence of compelling images and strong personalities (Interview 6; Kopper et al. 2007). These characteristics, as well as the sometimes long, consensus-seeking process of EU policy-making, do not match the media's interest in fast, exciting stories.

National media are of vital importance for a European public sphere, because, as one interviewee put it, pan-European media, such as EUobserver.com and the European Voice, are mainly 'village publications' that cater to a group of insiders (Interview 3). National frames of reference to a large extent determine the focus of Brussels correspondents and their editors back home (Interview 2; Kopper et al. 2007, 106). EU 
politics needs to be presented in a way that is understandable to citizens, and it is important that the significance of proposed legislation for national politics and society is clear. In early stages of policy-making the latter is often not the case. The result is a sometimes simplified and frequently delayed reporting on EU affairs (Sifft et al. 2007, 149).

Ever more organizations and political actors have a stake in EU affairs and try to influence the news agenda. For instance, civil society organizations and business lobbyists attempt to shape new policies and national governments try to frame EU policies as national success stories or obligations demanded by 'Brussels'. In this respect, the national focus also helps correspondents to deal with the huge amount of complex information, issued by ever more players. As one former journalist put it:

The problem for journalists is the vast amount of information that's poured over you, to find what is most interesting each day.... You just sort of make your own agenda.... But the defining factor is whether it's interesting to the viewers and listeners and readers in my country. (Interview 6)

Bijsmans and Altides (2007) illustrated these conflicting logics in a comparison of Commission press releases with Dutch and German newspaper reporting about EU affairs in 2003. Commission press releases often focussed on different issues than press coverage; there was an emphasis on different steps in the policy process; and media reporting sometimes presented a simplified account of EU affairs.

\section{Barroso I and information and communication policies}

Prior to proposals launched by the Barroso I Commission, the institutions had already taken certain initiatives to improve communication and information policies. For example, in 1995 the PRINCE (Priority Information Activities) programme was set up. It aims at fostering coopexation among institutions, member states and organized civil society and was quite successful at the time of the launch of the euro (Brüggemann et al. 2006, 5-8). Also during the 1990s, so-called 'Houses of Europe' were created, accommodating the Commission's representations and the EP's information offices in the member states. The Commission itself is the only institution to organize a daily press briefing, which Baisnée (2004 142) even calls the symbol of the control of the Commission over EU news'. Journalists go there to learn about the institution's policies and positions, but also to meet one another and exchange information.
However, despite these measures, the rejection of the Constitutional Treaty was partly seen as a result of a communications failure.

\section{Internal reforms}

The need for a more professional information and communication policy has gradually become a more important issue for the Commission. For example, as already explained, the number of organizations with a stake in communication about EU affairs has increased, which even shows during the daily press briefing. Spokespersons and PR officials from other institutions and various stakeholders nowadays attend the briefing to stay up to date and to contribute their own views (Interview 13).

Earlier attempts to professionalize information and communication efforts (European Commission 1994) were never fully supported. Andy Smith $(2007,233)$ writes that '[f]rom at least 1958 to 1999 , responsibility for communication within the College was a task that no Commissioner wanted'. Even when support was more widespread, important issues remained unresolved. For instance, while the Prodi Commission (1999-2004) introduced improvements in recruitment policy, organizational structure, and the coordination of media relations (European Commission 2002b), it was unable to tackle the lack of resources, the inadequate development of a communication culture, and the absence of direction and leadership (Anderson and Price 2008).

Many of these issues were addressed by the Barroso I Commission in its Action Plan (European Commission 2005a). In fact, the poor implementation of previous proposals was identified as one of three main issues, the other two being fragmentation of communication activities and inadequate sensitivity towards the interests of European citizens. The Action Plan proposed 50 actions, based on three principles - 'listening', 'communicating', and 'going local'. Several proposals seemed to take into account the media logic described in the previous section.

Proposals aimed at further professionalization, including proposals for tackling the fragmentation of the Commission's communication activities. For instance, the establishment of a planning and coordination team for communication matters should lead to more coherent messages. Involving the communication units in the DGs in the preparation of new legislative proposals should help to make communication part of every policy, not just an afterthought. An improved sensitivity towards the concerns and needs of European citizens was to be achieved by better press releases and by accompanying policy initiatives with a 'layperson's summary'. Adaptation to national and local concerns was to be stimulated by establishing a more central role in informing and 
communicating with national audiences for Commission representations in the member states and by attempting to adapt press releases to local and national audiences.

Importantly, the Action Plan focussed on all levels in the Commission, from the College to representations in the member states. Barroso I also acknowledged that the quality and quantity of means (including staff and communication channels) had to be improved to be able to take into account diversity of content, style, and target audience. Setting communication priorities and increasing the role of representations were seen as important steps in that direction. One could argue that the appointment of Wallström as Commissioner for Communication Strategy in Barroso I was in itself already an important step towards solving the lack of direction and leadership, some interviewees even called Wallström's influence crucial (Interview 5; Interview 6).

\section{Towards inter-institutional cooperation}

The documents issued by Wallström and her team also presented practical proposals and a guiding philosophy regarding what the institutions could do together. Plan-D for Democracy, Dialogue and Debate was a reaction to the 'no' votes in France and the Netherlands in 2005 and the European Council's subsequent call for a 'period of reflection' (European Commission 2005b). It was presented as part of a more encompassing development towards better EU communication that included the Commission's own Action Plan and the forthcoming 2006 White Paper on a European Communication Policy. The aim was to incite a broad debate that would continue beyond the reflection period. The document stressed that member states themselves are primarily responsible for organizing national debates. The white paper itself established communication as an 'EU policy in its own right' (European Commission 2006b, 4) and underscored the need for partnership among the institutions. Common principles should be defined and the institutions should coordinate their work to improve communication. Communicating Europe in Partnership made a number of practical propositions, some of which seemed to have been inspired by consultations with stakeholders, ${ }^{4}$ as well as comments from the EP (cf. European Parliament 2006a). Debate Europe presented further proposals, accompanied by an online discussion forum (European Commission 2008b).

These documents highlighted similar principles to those identified by the Action Plan, namely 'listening', 'going local', and 'partnership'. One could argue that, as such, they already provided an air of coherence and continuity. In fact, some of the terminology used was even reminiscent of that used in the 1990s (European Commission 1994). Importantly, the Commission stressed that communication was a two-way process. The EU should 'go local' by connecting to issues citizens care about and that often have a national or sub-national dimension, even though the corresponding policy may have originated at the European level. Institutions and member states, but also other involved or interested parties (organized interests, media), should cooperate in these efforts, because they would together benefit from a more democratic, citizencentred approach.

Whereas Plan-D (2005) was still mostly concerned with suggesting general recommendations to the member states (for example, to structure national debates as soon as possible), subsequent documents listed more concrete projects and ideas. These included a focus on new media technologies, setting joint communication priorities, developing so-called 'European Public Spaces' in the Houses of Europe (intended to host debates, exhibitions, and so on), cooperating with national parliaments and regional authorities, and establishing custom-made management partnerships in the field of communication among the Commission, the $\mathrm{EP}$, and individual member states. One of the most concrete proposals concerned an Inter-Institutional Agreement (IIA) on 'Communicating Europe in Partnership' that is discussed below (European Commission 2007b). It was stressed that Europe should be given 'a human face' and national, regional, and local dimensions should be taken into account to increase media coverage.

The lofty language set aside, the Commission initiated a number of changes and stimulated other institutions to also reconsider their communication efforts. Some member states showed an interest in cooperating with the Commission, such as the German government, the first to agree to a management partnership with the Commission in 2005. The Dutch government even drafted a communication strategy that was remarkably similar to the Commission's white paper, although an official from the Dutch Ministry of Foreign Affairs called the overlap between both documents 'unintentional' (Interview 7). ${ }^{5}$

\section{Challenges}

The Commission's proposals resonated with issues deemed important by journalists, such as the need to explain EU legislation in terms of what it meant for national settings, but they also corresponded with the key challenges identified by scholars. In addition, the renewed emphasis on information and communication was endorsed by the EP (European 
Parliament 2006a) and the member states (European Council 2006). Some interviewees even noted that the need to communicate better was becoming more widely acknowledged within the institutions (Interview 7; Interview 8). However, as Meyer (2009, 1059-1060) has argued, the rate of change has been only incremental. The Commission's ideas increasingly became the focus of political discussions and established practices also proved to be rather persistent, both within the Commission and between it and other institutions.

\section{Challenges within the Commission}

The politics of information within the institutions can frustrate information and communication, even leading to conflicting messages. In the case of the EP, internal differences are less of a hurdle than a necessity because different political opinions characterize democratic parliaments. However, dealings with other institutions and with external partners often necessitate a common approach by the member states. At the same time, relations with national electorates and parliaments require ministers and $\mathrm{EU}$ leaders to be able to communicate policy outcomes with a view to national implications.

Similar problems also apply to the Commission. Commissioners, DGs, and units regularly disagree about policies. Andy Smith $(2007,235)$ notes that 'the College is an arena for political competition within which practices of information and communication are jealously guarded resources for advancing ideological preferences, national or sectoral interests and personal careers'. This can partly be explained by the fact that the Commission needs to constantly shift between roles. Often, a neutral stance is in its best interest, certainly when proposing new legislation. Yet in other cases the Commission has to defend the EU's core aims and policies, for instance when national laws do not comply with EU legislation (Kopper et al. 2007, 106-109; Meyer 2009, 1054-1055). This results in conflicting demands on information and communication efforts and conflicting interests among different layers within the Commission. This affects all layers in the Commission and, hence, leadership remains an issue.

Two sets of examples illustrate the competing interests within the Commission. The first concerns interaction with press and public. Brüggemann et al. $(2006,18)$ write that press releases are often seen as 'either too technical or not precise enough, quotes from commissioners are criticised as meaningless and the quality of translation (if available) is not always up to the standards that many journalists expect'. Kopper and colleagues $(2007,103)$ write how Commission spokespersons work together with DGs to write the announcement texts for the midday briefing. The way in which these texts are produced regularly means that while spokespersons produce eloquent drafts, revisions by others tend to have the reverse effect:

The initial, sometimes crisp drafts by spokespersons or their staff are routinely rephrased by the DGs, and hence, retuned, softened, and often 'jargonised' which makes them much more cryptic due to frequent overwhelming legal advice that they are exposed to in-between and beforehand.

The tension between political and media logics is eminent here, with officials trying to avoid unwanted debates. ${ }^{6}$ As Meyer $(2009,160)$ writes, the Commission's 'strength is communication with various stakeholder groups, but it struggles to adjust to increasing media attention and pressure to seek publicity'.

The second set of examples concerns internal support for the Commission's information and communication priorities outlined above, such as the need to increase coordination. Cooperation between DG COMM and the communication sections in other DGs is mostly ad hoc (cf. Martins et al. 2012, 314). Interviewed Commission officials explained that some DGs are more willing to communicate than others. One interviewee commented on the 'political background' of portfolios that leads to different perceptions of if, how, and who to inform (Interview 9). Another interviewee put it like this:

Wallström and her DG have to convince other DGs. Some are sensitive towards communication. Others are policy-making machines and communication with citizens is very far removed from what they do - it doesn't have the priority it should have.... Some do very well, such as DG Budget and DG Energy. Internal Market and Competition hardly do anything. (Interview 8)

These examples show that the aim for a culture in which information and communication are central tenets remains restricted by a reality in which these do not always have priority (cf. Brüggemann 2010, 15). For instance, when asked about the influence of national public debates on changes to air quality policies in 2005 , one interviewee explained that these debates did not have a direct effect on the new proposals because Commission policy-makers did not follow media reporting in the member states on a daily basis. More important were early efforts 
by officials from one member state (the Netherlands) to influence forthcoming proposals (Interview 14). ${ }^{7}$

Perhaps more importantly, despite changes in the concours, many involved in communication are not experts, but civil servants. They were selected based on technical expertise and trustworthiness, not communication and media knowledge. Even though this has gradually changed, as recently as 2008 a Commission official said it felt like being 'Alice in Wonderland' (Interview 8). ${ }^{8}$ In his opinion, proper communication requires sufficient knowledge and personnel, which are both lacking, due to which efforts remain rather amateuristic.

\section{Communicating in partnership?}

The institutions have distinct roles and diverging interests in EU politics. This has an influence on attempts to harmonize communication. Several interviewees raised this issue, including a Commission official dealing with communication policy (Interview 8). For example, one EP official argued that the EP is a 'political body', whereas the Commission is mostly an 'executive body'. As a result, their messages differ in style and content (Interview 4). A former Council official simply called the institutions 'competitors' (Interview 10).

Differences regarding expectations and intent are also reflected in the documents on information and communication. For instance, the directly elected EP considers itself to be best suited to play 'a leading role in the European dialogue' (European Parliament 2005a, 7). The establishment of EuroparlTV may be considered a case in point - something not everyone in the Commission was too keen about (Interview 11). The Commission itself argues that stimulating public discussions about Europe is 'first and foremost the responsibility of the public authorities in the Member States' (European Commission 2006b, 5). Meanwhile, the member states envisage a 'special role' for the Commission. ${ }^{9}$

In practice, cooperation among institutions has indeed proved to be difficult, even at the most basic level. For instance, while the establishment of 'Houses of Europe' is valued positively, Commission and EP representations tend to duplicate work on information and communication matters, such as the organization of public events in member states (Brüggemann et al. 2006, 16). Martins et al. (2012, 313) report interviewees referring to overlapping institutional agendas as a complicating matter: important Council meetings that take place in the same week as the EP's Strasbourg plenary, and Presidency press conferences that overlap with press conferences of ministers, to name but two examples.
National involvement is also not a given. For instance, in the aftermath of the rejection of the Constitutional Treaty, the EP had called on national parliaments to cooperate in so-called 'Parliamentary Forums' (European Parliament 2005a, 6-7). Yet, according to Kurpas et al. $(2006,1)$, reactions from national parliaments were ' $\mathrm{Cool}^{\prime}$, reflecting 'the limited commitment among many national decision-makers to actively make the case for European integration'. Strategic reasons have often been decisive in the member states' considerations. As Mitchell Smith (2000, 170) explains, 'the myth of a grasping, bureaucratic, centralizing, unaccountable "Europe" embodied in the European Commission can be extremely useful in domestic politics'. National politicians tend to blame the EU when policies do not turn out as planned or when they have been 'forced' to adopt unpopular decisions. Not surprisingly, one Council Secretariat source remarked that what ministers say during press conferences regularly differs a lot from what they said during Council meetings (Interview 12).

The failure to reach consensus on an Inter-Institutional Agreement is a good illustration of how different perspectives limit the promise of inter-institutional cooperation. The Commission presented a first proposal in 2007 , making a case for selecting communication priorities that would be laid down in a common annual work plan (European Commission 2007b). The efforts were to be assessed in an annual debate in the EP and by the Inter-Institutional Group on Information. ${ }^{10}$ Yet, as one Commission official explained, problems arose immediately:

There has been a very tense atmosphere around this project. First, because of political reasons; secondly, because of procedural reasons. The Council did not want Parliament to participate in the negotiations in the Working Party on Information and only now allows Parliament to come in. Which we do understand in procedural terms, but the way in which it happened was not so ideal and there was also then a certain mismatch in terms of steering the process in diplomatic terms. (Interview 9)

The Commission constantly had to navigate between the positions of the other two institutions. Officials in the Council Secretariat emphasized that only day-to-day cooperation would be possible:

The basic thing is that there is no chapter or article about communication policy in the treaties.... There is no legal base for [an] EU communication policy with a huge budget, with millions of euros, because member states did not want that. (Interview 12) 
The member states were also divided. Due to historical reasons, some of the Eastern European member states were not in favour of 'organised information' (Interview 9). Even Germany, the first country to have concluded a management partnership with the Commission, was afraid that an overarching framework might limit the freedom to communicate. In the end, the institutions settled for a less forceful political declaration on 'Communicating Europe in Partnership'.11

\section{Conclusion}

This chapter has illustrated how the politics of information affects $\mathrm{EU}$ information and communication policies. Internal institutional dynamics, relations among the institutions, but also the tension between political and media logics are important in this respect. The EU institutions struggle to engage with the public. Citizens, for their part, may get a skewed image of what the Union looks like and how it functions, something that complicates holding those to account who draft and decide on policies. Such challenges also influence national politics (Eilders et al. 2004, 221). However, compared to EU affairs, this may be less problematic as people tend to have a better insight into and more knowledge about national politics.

EU institutions have taken several initiatives towards improving information and communication efforts, ranging from the web-channel EuroparlTV introduced by the EP (Shackleton, this volume), to a Council study into trends in the information and communication policies of the member states (Council of the European Union 2006). Nevertheless, despite the European financial and sovereign debt crises being prominent all over the news, and the Lisbon Treaty having further strengthened the $\mathrm{EP}$, as well as the EU's role in several policy fields, the active focus on information and communication policy seems to have withered.

This is illustrated by the fact that there no longer is a special Commissioner for Communication, as was the case with Wallström. Today DG Communication falls under the responsibility of Commission Vice-President and Commissioner for Justice, Fundamental Rights and Citizenship, Viviane Reding. After she took up her post in February 2010 , Reding indicated that communication would remain 'a strategic priority' ${ }^{12}$ Yet the stream of initiatives from DG Communication appears to have dried up, the last initiative dating from $2009 .{ }^{13}$ Asked about Reding's commitment to communication, one Commission official said that 'most efforts of Vice-President Reding at communication are aimed at promoting herself and her own political agenda' (Interview 15).

\section{Interviews}

1 Official, DG Communication, 17 January 2007, Strasbourg

European Parliament

European affairs journalist, representative International

Press Association (API-IPA)

Official, Press Service,

European Parliament

Official, Press Service,

European Parliament

Eurme Pan

$5 \quad \begin{gathered}\text { Former German Brusse } \\ \text { based TV journalist }\end{gathered}$

$6 \quad$ Former Finnish Brussels-based TV journalist

7 Official EU Unit, Information and Communication

Department, Dutch Ministry

of Foreign Affairs

Official, European

Commission

Representation, the

Netherlands

Official, DG Con

European Commission

10 Former official DG F, Council

Secretariat; former press

officer Finnish Permanent

Representation

11

Official, DG Communication European Parliament

2 Double interview officia Press Unit and official Communication Unit, DG F,

Council Secretariat

Spokesperson, Dutch

Permanent Representation

13

Official, DG Environment

European Commission

Official, DG Justice, European

2 July 2007 , Brussels

3 July 2007, Brussels and 14 April 2008, Brussels

14 April 2008, Brussels

15 April 2008, Maastricht

15 April 2008, Maastricht

28 April 2008, The Hague

14 May 2008, The Hague

23 May 2008, Brussels

23 May 2008, Brussels

5 June 2008, Brussels

10 June 2008, Brussels

10 July 2008, Brussels

31 August 2010, telephone interview

29 November 2012, Brussels Commission

\section{Notes}

1. The author would like to thank the editors and the other contributors to this volume, as well as the participants in the panel on 'Media and Governance' at the 2012 NIG work conference for comments on earlier versions of this chapter. 
2. Declaration by the Heads of State or Government of the Member States of the European Union on the Ratification of the Treaty Establishing a Constitution for Europe, SN 117/05, Brussels 18 June 2005.

3. Although beyond the scope of this chapter, it is clear that the emergence of new social media has repercussions for both logics (see e.g., Sanders 2009).

4. For example, the stakeholders' forum on 'Bridging the Gap: how to bring Europe and its citizens closer together?', organized by the Commission together with the European Economic and Social Committee on 7 and 8 November 2005 in Brussels, and attended by the author.

5. Tweede Kamer, vergaderjaar 2007-2008, 31 202, nr. 9 herdruk.

6. See also Shackleton's comments regarding 'bureaucratic efforts' versus 'journalistically interesting programme material' in the context of EuroparlTV (this volume).

7. See Bijsmans (2011) for more information about the respective cases.

8. In a similar vein, one EP official said that all those involved in communicating the affairs of the institutions are 'gifted amateurs' (Intervie w 1).

9. For example, Declaration by the Heads of State or Government of the Member States of the European Union on the Ratification of the Treaty Establishing a Constitution for Europe, SN 117/05, Brussels 18 June 2005.

10. This body was set up in 2002 and brings together representatives from the Commission, the Council and the EP to discuss information and communication matters.

11. Communicating Europe in Partnership, OJ 2008, C13/3-4.

12. 'Communicating Europe begins at home, says Reding.' EurActiv.com, 15 February 2010. Available online: http://www.euractiv.com/priorities/ communicating-europe-begins-home-says-reding

13. See: http://ec.europa.eu/dgs/communication/about/what_we_do/index en.htm. Last accessed 30 January 2013.

\section{3}

\section{The European Parliament 'On Air'}

\author{
Michael Shackleton
}

\section{Introduction}

It is extremely common to point to the inverse relationship between the increase in the powers of the European Parliament (EP) and the decrease in popular involvement with the institution, at least as measured by electoral participation. Even the prospect of the entry into force of the Lisbon Treaty, granting the institution almost equal powers as the Council of Ministers in framing legislation and the budget and making it arguably the major winner of that Treaty (Shackleton 2011), did not entice more than 43 per cent of European voters to take part in the June 2009 elections to the Parliament, the lowest figure since direct elections were introduced in 1979.

At least part of the explanation for this lack of participation can be found in the nature of the institution. It remains an 'unidentified political object', one that European citizens do not strongly identify with as part of the system of government that affects their lives. For the mainstream media in all countries, national parliaments remain much more important than the distant European Parliament, whose multilingual debates cannot match the cut and thrust of domestic politics among adversaries who are well known to those reading the papers, listening to the radio, or watching television.

The situation is one that the Parliament itself has made strenuous efforts to remedy. It has devoted considerable resources to providing information to the media and to finding ways of communicating with European citizens directly. It has a Directorate General (DG) for Communication with more than 600 staff, a figure unmatched by any other parliament in the world. The DG has traditionally invited journalists to visit the Parliament in Brussels and Strasbourg, ready to face 